Jagoda Komusińska

Cracow University of Economics,

Faculty of Economics and International Relations

e-mail: j.komusinska@interia.pl

\title{
Economics as a Discipline of Instrumental Reason. Looking at Economics as a Science from the Perspective of the Frankfurt School of Philosophy
}

\begin{abstract}
The article is built around the analysis of The critique of instrumental reason by Horkheimer, applied to issues connected with the philosophy of economics. Positive economics is under-stood as an example of a discipline where the pragmatic paradigm has been implemented. Therefore, economics functions within the boundaries of what Horkheimer called instrumental rationality. The starting point is the intellectual source shared by economics and the Frankfurt School, namely Kant's philosophy of rationality. In the first part of the article, three of Kant's ideas that are fundamental to economics are presented, and then the development of their application in philosophy of science, as seen by Horkheimer in 1947, is laid out. The second part of the article consists of enumerating various distinctive features of economics that set it apart from other social sciences and which constitute factors for which it can be considered a realm of the reign of 'instrumental rationality', with all the threats such an approach provokes. The above-mentioned features concentrate on treating humans in economics as a means, not as a goal. This aspect of the philosophy of science of the Frankfurt School (unlike its critique of capitalism as an economic system) has not been widely received.
\end{abstract}

Keywords: Frankfurt School of Philosophy, economics, Horkheimer

JEL Classification: B40, B41 


\section{Preliminary remarks}

In the article, culture is understood as the universe of human activity that is typical only of humans: it encompasses everyday life practices, legal and political systems, economic relations and everything else that may have no connection to the narrowly understood idea of culture as a creative/artistic activity. The term economics many times will appear as an abbreviation for positive economics (engaged by every school of economics) and also for such examples of normative economics, in which the relation between human beings and the economy is the same as in positive economics. Although the present article refers only to the Critique of Instrumental Reason by M. Horkheimer, there will be a few places where the surname of its author will be exchanged with the term 'the Frankfurt School', created by Horkheimer together with T. Adorno, because Horkheimer's text is a cohesive completion of the ideas that he expressed together with Adorno.

\section{Introduction}

On what basis can an analysis of cultivating positive economics be made from the perspective of critical philosophy? In their critique, the Frankfurt School authors referred (1) directly to the ideas introduced by Kant, generally accepting them (however with certain modifications) and (2) to the heritage of the Enlightenment, including especially the heritage of Kant's philosophy that was used by positive philosophy and later, pragmatism. At the same time, basic concepts of economics as a scientific discipline also come from the very same source: the philosophy of Kant, and its transformed, positive and pragmatic versions.

Moreover, looking at modern-day economics through the Frankfurt School lens seems even more interesting given the fact that its critique was aimed explicitly mostly against the phenomenon of the economisation of the human cultural environment, ${ }^{1}$ therefore its concepts deal with the economic practices of capitalism, which is partially supported by the theory of economics.

What is symptomatic of the chasm between economics and philosophy is that (1) this question did not meet with much interest among economic theorists ${ }^{2}$ and (2) nor did Horkheimer himself notice the direct relationship between the intensely pragmatic, imperialistic philosophy of economics and the all-devouring economisation of social life, although he described pragmatism that pervades the philosophy of science in theory and the pragmatisation (economisation) of culture in social

\footnotetext{
${ }^{1}$ M. Horkheimer, T. Adorno, Dialektyka Oświecenia. Fragmenty filozoficzne, Wydawnictwo IFiS PAN, Warsaw 1994.

${ }^{2}$ The very issue presented in the article has been partially analysed in the essay by H. Stewart, A critique of instrumental reason in economics, "Economics and Philosophy" 1995, Vol. 11, pp. 57-83.

Usually, texts on economics written in the paradigm of critical theory are concentrated on the normative aspects of the economy and management (which means they critique capitalism as an economic system). They do not focus on the philosophical ground of rationality in economics.
} 
practice. Horkheimer's critique was addressed precisely to pragmatic philosophers. As a 'professional' philosopher, Horkheimer forewent the possibility of talking about particular disciplines of science and their domains, stating that 'economic and social aspects of modernity are the object of studies of competent scientists.' 3

The fact that his philosophical, general and non-pragmatic thought can be applied 70 years later to the analysis of a specific field of economic science is one of many proofs of the intellectual superiority of philosophy.

\section{Kant and economics}

A. Smith is considered the father of the theory of economics. In 1759, for the first time, he mentioned 'the invisible hand', a mechanism thanks to which the sum of particular egoistic, antagonistic interests of individuals brings the maximisation of happiness to society as a whole. Although it lacked logical explanation and the 'hand' seemed supernatural, it was accepted as the cornerstone of economics. It proves to be highly useful as it frees the individual from responsibility towards others for undertaking egoistic decisions. Had economics appreciated a more abstract, generally important philosophy, Kant could be well introduced as its real father. Kant (1) explained the invisible hand mechanism in a rational way, (2) re-defined the idea of progress, which is central to economics and (3) defined its ontological field of interest in the frames of what he called practical reason.

Kant did not believe in the possibility of moral transformation and progress of an individual in the history of mankind, because man was scared with an inherent, a-historic, 'radical' evil, which manifests itself through his egoism. But, at the same time, he claimed that the progress of mankind is possible and it can be manifested in the legal and political structures of the society. History indeed presented the emancipation of mankind from barbarism to civilisation, from despotism to republics. Individual people do compete with each other for resources, but they have a reason, and thanks to this reason they learn that they can also cooperate (through the so-called 'asocial sociability'). The egoistic and 'reasonable' elements collide constantly and this dynamic process brings the gradual improvement of social morale, meaning: an increase in the domination of 'civilised' ('reasonable') elements over 'natural' ('egoistic') ones. In this way, thanks to reason, a human is not able to completely eradicate the beast inside him, but he learns how to effectively tame it. Kant treated this 'reason' as the most effective organ that substitutes claws and tusks in humans and enables them to survive in nature. Thanks to reason - wit, intelligence, the ability to forecast and calculate - people managed to become something that is above nature. ${ }^{4}$

Progress is a never-ending process and not a state. It never stops, it has no definite purpose. 'Enlightenment', which is a synonym for progress, has no other reason than dynamic endurance. Kant was anti-utopian in the sense that he did not

\footnotetext{
${ }^{3}$ M. Horkheimer, Krytyka instrumentalnego rozumu, Scholar, Warsaw 2007, p. 35 (translated by J.K.).

${ }^{4}$ Z. Kuderowicz, Czy Kant wierzyl w postęp? [in:] Kant wobec problemów wspótczesnego świata, eds. J. Miklaszewska, P. Spryszak, Jagiellonian University Press, Cracow 2006, pp. 13-17.
} 
believe that mankind will ever achieve, once and forever, a state of optimal conditions; he did not try to delineate such conditions of 'the fulfilment of progress' and he was convicted that no one should ever impose his finalist model of general happiness onto individuals. ${ }^{5}$ A direct analogy to how economists treat economic growth can be clearly seen. In all the economic models and recommendations, economists never tend to indicate the possibility of achieving the final end of ongoing efforts, work, renunciations or postponing pleasures for 'later'. ${ }^{6}$

\section{Kant and Horkheimer}

The type of rationality described above, used to obtain the effect of 'the invisible hand' and collective progress, Kant called 'practical reason'. Practical reason means the human ability to efficiently function in public life. It is a kind of an instrument. This type of rationality determined most important concepts of economic mechanisms and many economic ideas. However, apart from practical reason, above it Kant placed a different feature that all people are equipped with - theoretical reason. The latter enabled people to acquire scientific knowledge, contemplate, discover the secrets of the world and make contact with the absolute. 150 years after Kant, Horkheimer noted that the way in which Kant's system of two rationalities was applied in the thought of $19^{\text {th }}$ and $20^{\text {th }}$ century philosophical movements was aberrated and was characterised by favouring practical reason. First, domination of practical rationality took the form of positivism, which saw as scientific facts only those phenomena that could be proven in the way of empirical experiments or presented with the use of mathematics (and which renounced all those phenomena which could not be proved in such a way). Later, it became more radical with the advance of pragmatism, which not only demoted any non-sensual cognition, but which scornfully rejected any need for pure thinking, abstraction and speculation that would not serve particular interests, but was instead autotelic. As Horkheimer saw it, pragmatism was an anti-philosophy, an 'anti-intellectual Darwinism' that undermines fundaments of rationality as understood by Kant (as Kant included both types of rationality, theoretical reason being autotelic). Pragmatism is directed towards pure utility because it negates the very existence of theoretical reason as a 'reason'. Pragmatism does not seek to find the 'meaning'; moreover, it treats as 'meaningless' everything that deals with 'meaning'. And as the nature of human beings is directed at making the world meaningful, pragmatism is anti-humanistic.

Horkheimer created a pair of opposing types of reason in analogy to Kant's dichotomy of practical/theoretical. He described two types of rationalities: objective and subjective/instrumental. They are both integral and nonerasable components of

\footnotetext{
${ }^{5}$ J. Miklaszewska, Kantowska utopia racjonalności [in:] Kant wobec problemów..., op. cit., pp. 75-86.

${ }^{6}$ Compare: J.M. Keynes, Economic Possibilities for Our Grandchildren [in] Essays in Persuasion, Macmillan London 1931, pp. 358-374.

From today's economics perspective this text can be considered a proper utopia, as Keynes, a human-oriented economist, supposed in it that by the $21^{\text {st }}$ century people would not have to work any longer as an effect of having obtained a sufficient techno-economic level of development.
} 
rationality. Throughout the history of mankind they have competed for domination and they both have imperialistic tendencies. Objective rationality reigned until the Enlightenment. Objective rationality is a substantial, all-encompassing being of metaphysical nature, a universal order, and man tries to find his place in this order, to tune in into the harmony of the universe. The human being - as an element of the universe - is also equipped with objective rationality. When he uses it, it means he is alert to read how rationality is manifested in the world and to adjust his behaviour to what this rationality requires of him. The aim, and also the synonym of objective rationality, are all the highest values, like: truth, good, freedom and justice. ${ }^{7}$

When put into historical context, philosophical structures based on such rationality were embedded in religious systems, in which the final source of all the abovementioned values was God. During the Enlightenment, philosophy rejected socially oppressive religious systems and focused solely on the human being - on his dignity and his inherent freedom. Human beings were granted these qualities because they were endowed with reason, with rationality (which made them conscious and distinguished them from animals). Human reason - a guarantee of their dignity - was not referenced to any external instance. In this way, Enlightenment brought the idea of rationality to subject (person) - therefore rationality became subjectified. Subjective reasoning is an attribute, a disposition of a man. It rejects granting rational foundations to any general ideas (like values). It does not seek aims; it even negates the sense of having any aims or values. It is only interested in how to properly choose the most suitable means for a given aim. The domain of subjective rationality lies within classification, deduction and calculation. Just as Kant's theoretical reason that was directed at discovering truth was an emanation of objective rationality (theoretical reason strives to find the truth because it believes that truth exists in the world), practical reason, treated as an instrument of evolution (it is what separates humans from other animals) is how subjective rationality is manifested.

The paradox of the domination of subjective rationality lies within its tendency to completely eliminate objective rationality (as 'unjustified' on the grounds of subjective rationality), as it exists in the world of humans, and the structure of this world involves the existence of both means as well as aims. The moment in which rationality limits itself to the sphere of organising means, it leaves the sphere of setting aims completely out of the competence of any rationality at all, which means it gives up the aims of human life as an easy prey for irrationality - all that Kant called 'nature' (identified with egoism), the opposition of practical reason. Rationality 'abdicated (...) from evaluating human deeds and human way of living. It left this task to antagonised particular interests, and our world seems to be truly their prey. ${ }^{8}$ In effect of this: "spiritual imperialism of the abstract rule of self-interest [leads to the situation where] no functional, rational rule of social cohesion was saved (...), all the substance of rationality was arbitrarily reduced to only one of its components, it was closed in the frames of only one of its rules; what was particular took over the place of what was general."9

\footnotetext{
${ }^{7}$ M. Horkheimer, op. cit., p. 38.

${ }^{8}$ Ibidem, p. 42.

${ }^{9}$ Ibidem, pp. 50-51.
} 
In times before the Enlightenment, religion, as a medium of spiritual objectivity, would integrate scientific cognition within it (the most prominent example of such a structure being Thomism). In the aftermath of the Enlightenment (in the time of the reign of positivism), religion was not eliminated from the world, but religiousmoral order - still responsible for establishing the aims of human life - was completely separated from scientific order, which defined itself as rational (subjectively rational) and was preoccupied with elaborating suitable means. Technocracy became the philosophy of science. As this technocracy progressed, it took the form of pragmatism, claiming that choosing the right means was science's final and only reason for being, and science's 'vocation' was to be consistent, stable and in constant movement (the terms in economics used to describe desired economic growth). Rationality, understood only as a means for adaptation that enables the individual to survive, capitulates in front of the strive to change anything in the world. The only thing a 'reasonable' individual can do is to accept the 'irrational' world as it is and to adapt to it by 'divesting oneself of stubbornness'. ${ }^{10}$ In such conditions, even social moral progress as Kant saw it is impossible. From the point of view of instrumental reason, cruelty and violence are not evil per se, if they are considered as means to something else. On the other hand, no aim - be it happiness or even wealth - is valuable enough to be the merit per se, and it cannot be proven that happiness or wealth constitute an aim better than any other. Which leads to irrational relativism: 'If one would cling consistently to the scientism theory (...) [it should be acknowledged that - J.K.] there are no horrible deeds or inhuman relations, and that the evil that is seen is merely imagined.' ${ }^{11}$

\section{Horkheimer and Economics}

Horkheimer conducted a dialectic analysis of the effects of subjective rationality domination in philosophy and society for legal-political, psychological and economic dimensions of human life. In the political sphere instrumentalisation leads from despotism through republicanism to fascism. In the psychological dimension, the superficial rationalisation of instincts (human self-interest is treated as rational, but only as far as it serves as a tool to civilise the nature external to humans) gives rise to an authoritarian personality.

In economic practice, the turn towards subjectification is represented by the transformation from perfect competition to monopolisation. Monopolists do not have to rationally negotiate their egoistic aspirations, because these are not met with opposition on the side of the 'masses,' taught to passively accept reality as it is and to adapt to it. While in the perfect competition model actions and reactions can enact automatically ('the invisible hand'), in the later phase of development of capitalism, an action manifests unbalanced premeditation and violence. ${ }^{12}$ Horkheimer undermines the belief in the 'invisible hand':

\footnotetext{
${ }^{10}$ Ibidem, p. 42.

${ }^{11}$ Ibidem, p. 41.

12 Ibidem, pp. $157-158$
} 
Liberalism with its levelling rule of trade and exchange, which used to bond liberal society, brings conformism as its effect. The monad, the $17^{\text {th }}$ century symbol of the atomised individual as an economic subject (...) became a social type. All these monads, although separated from each other with the moats of their egoism, in their struggle for their own purposes, started to become more and more similar to each other. In our day of economic trusts and mass culture, the rule of conformism sheds the appearance of individualism, it is proclaimed openly and elevated to the position of a per se ideal. ${ }^{13}$

Technocracy and pragmatism work well in technical and natural sciences, because the object of their endeavours is the material world, but not in social sciences. 'Social' means that their field of study is related to the type of existence that is only typical of humans and the distinctive feature of humans is that they are concerned with immaterial values. This very characteristic was the reason, why - in the course of the enlightened humanistic thought - man was considered the centre of rationality, dignity, freedom and individuality (which are all immaterial values). Man - according to the original idea the source of spontaneity and creativity - loses his subjectivity when he treats the act of thinking as a mechanical movement of thoughts that does not refer to anything external to itself. ${ }^{14}$

\section{The effects of instrumetalising reason - positive economics and social sciences}

Economics is a social science. However, it is not a humanities discipline. Also, in the scope of its research is it very distinctive from all the other social sciences. It differs in its methodology based on mathematical models and quantitative calculations, but, what is more important, it differs in the final reason of its cultivation. The level of instrumentalisation of rationality in economics can be noted through its comparison with other social disciplines. The aim of sociology is to understand man through his functioning in societal structures; the aim of psychology is to understand man through his emotional-intellectual construction; the aim of cultural studies is to understand man through the civilisation that he creates; and so on; finally, the aim of philosophy is to understand man through analysing his essence. Legal and political studies also place human beings at the centre of their interests as they deliberate over what is just and how to guarantee respecting human dignity. In the meantime, the central issue of economics is the economy. What lies at the roots of economics scientific consideration is not the attempt to understand man through his activity in the field of exchange of goods or management of resources. The aim of understanding man is to understand economic activity. Formal economics tends to favour such a juxtaposition of people in their social functions that will provide most

\footnotetext{
${ }^{13}$ Ibidem, p. 144.

${ }^{14}$ See: C. Korsgaard, The Constitution of Agency: Essays on Practical Reason and Moral Psychology, Oxford Scholarship Online, Oxford 2009, pp. 25-99.
} 
dynamic and most stable economic growth. Whereas one might suspect that there is an implicit, final aim to this procedure (which would be associated with human happiness), this supposition cannot be justified on the grounds of economics for several reasons.

(1) Most of all, human beings in economics are treated as a resource - 'human resources' generally do not matter for economic growth any more than capital or land/technology. No other scientific discipline ever elaborated a term that would be so anti-humanistic. Of course, there are economists who ascribe 'human resources' with a key-role in the economy, but still it is only a role that people play in their goal of achieving economic effectiveness. And if an object is considered a means (factor), it is impossible for it to be an end (aim) as well. The canon of economic models does not present economic interdependencies, on which human happiness relies, but models in which human resources are correlated with another factor influence the economy in a certain way. The alternative, in the form of e.g. evaluating national economies on the basis of the level of happiness of their citizens, is still treated by most economists as a para-economic equivalent of 'alternative medicine' in medicine.

(2) The second inherence of economics which discredits the belief that anything other than the economy can be its final aim is constituted by the fact that the prerequisite rule of economics is the suspension of casting moral judgements on individuals' deeds, which is supposed to assure that it remains always objective. This objectivity allows economics to be qualified in the group of positive sciences. Differentiating actions of individuals from a moral point of view, according to economics, is practically non-viable. Whereas all other social sciences undertake this effort (which, in turn, often transforms them into ideologies, as Horkheimer remarked), economics prefers to simplify the issue and treat each and every moral preference of individuals with the same, null attention, in order to be able, on this simplified basis, to construct its abstract models of actions of these unified 'human resources'. Both in theory and in practice, it means that economics allows e.g. the mass starvation of people in a global economy where resources are not scarce any more (global food production exceeds global demand for food) because all preferences of all individuals in the world have the same weight. Such a situation can only be considered economically unfavourable because it causes a deterioration in 'human resources', which would indicate that such an apprehension of human preferences is ineffective. ${ }^{15}$

(3) Finally, economics still claims to be objective, refusing to accept the accomplishments of the post-modern philosophy of science, whose representatives noted that no social fact is ever independent of the historical, social, economic and

\footnotetext{
${ }^{15}$ What is paradoxical is that a society which - faced with people starving in large areas of the globe allows for a large portion of its machines to remain unused, does not implement many glorious inventions and dedicates uncountable hours of work to the idiotic advertisement and production of annihilation weapons - a society that affords such a luxury made productivity its gospel (M. Horkheimer, op. cit., p. 147).
} 
psychological conditions of the subject which draws his attention to it. ${ }^{16}$ The selection of variables included in economic models is not accidental, but implicitly manifests a certain approach of the economists and the variables contain an unspoken interpretation. Economists state that they refrain from casting any judgements, but given this knowledge, an effective lack of any criticism (condemnation) of individuals' behaviour is equivalent to actively supporting all of them.

However, economics does not limit itself to what is currently the economy. Analogous to all other social sciences, it is characterised by a tendency to step into the research fields of psychology, sociology, cultural studies and so on. Yet it does not admit to being 'interdisciplinary' or equal with other disciplines, and it tries to impose the rigours of its models onto other dimensions of human existence. A philosopher can propose interesting insights into sociology or culture and an anthropologist can delve into pedagogy to understand his prime domain better. The influences between disciplines in social sciences are reciprocated, commonly acknowledged and respected. Whereas when economics engages in studying e.g. culture, it treats the accomplishments of culture researchers (philosophers, sociologists) with ignorance and arrogance, even if they had elaborated many theories and ideas that would explain economic aspects of people's cultural practices (e.g. Bourdieu, Baudrilliard or Horkheimer). Economics imposes the economisation on non-economic aspects of life while stating that economisation (which usually is synonymous with marketing) is only an invisible form, which does not influence their substance and particularity. In this sense, economics is not a phenomenon, but a process, which can be shared by any phenomenon. Using the famous metaphor of M. McLuhan, in its approach to other social sciences, economics is a medium, but a medium, which becomes the message. ${ }^{17}$

Economics is tangled in non-economic, social aspects of human life. The claimed morally unbiased attitude does not mean that economics is a truly and completely 'positive' science (meaning that it treats all phenomena as good). In the economic realm some phenomena are positive and some have negative connotations. The latter group is composed of all things that do not boost economic growth everything that is unproductive. According to Horkheimer, common social acceptance of 'activism' is one of the main features of instrumental reason: 'All those forms of activity which are not productive are stigmatised as senseless or redundant, as a luxury. (...) Productive work - both physical as well as mental - brings glory; indeed it is the only accepted way of living, and a productive action is any such action, any pursuit of any aim that brings profit. ${ }^{18}$ The interest of the economics is

\footnotetext{
${ }^{16}$ For a comprehensive overview of opinions of whether economics can be treated as a 'positive' science, see: J. Dzionek-Kozłowska, Ekonomia jako nauka pozytywna. Refleksje na marginesie "Ekonomii dobra i zła” Tomasa Sedlacka, “Annales, Etyka w życiu gospodarczym” 2013, nr 16, pp. 335-344 (the English translation of the article was published in Ethics in Economic Thought. Selected Issues and Various Perspectives by J. Dzionek-Kozłowska and R. Matera, Lodz University Press \& Jagiellonian University Press, Lodz-Cracow 2015, pp. 81-89).

${ }^{17}$ M. McLuhan, Zrozumieć media: przedtużenia człowieka, Wydawnictwa Naukowo-Techniczne, Warsaw 2004.

${ }^{18}$ M. Horkheimer, op. cit., p. 67.
} 
not limited to those areas of people's lives, in which they engage in economic turnover. Economics is hegemonic and does implicitly cast judgements about how people live their whole lives, how they allocate time between 'economic' (positively valued) and 'non-economic' (negatively valued) activities. For example, a well-educated mother who decides to dedicate 5 years of her life to raising a child is an economically inexplicable loss (although she can redeem her position for the economics as a voracious consumer). Particularly, experiencing pleasure that does not involve consumption or regenerating forces for upcoming work - are economically suspicious. ${ }^{19}$

\section{Final remarks}

The description of how economics limits itself to using instrumental reason and its anti-humanistic orientation might not be alarming were is not for the uncommonly pro-active attitude of economics which thrives in elaborating policies and influencing economic realities. No other social science (e.g. political studies) translates into common social practices so easily and widely. The precipitated activism and pressure of obtaining measurable results in economics as a scientific discipline is a reflection of the pragmatic paradigm dominating people's economic practice. Why at all should anyone talk about economics through the perspective of philosophy? Is it not the nature of economic mechanisms that induces the effective/ineffective opposition? And does economy not lie 'beyond good and evil'? Horkheimer proves that, after all, every aspect of existence that is typical of mankind - be it science or economy, or economics - can be philosophically, critically reflected upon.

\section{References}

Dzionek-Kozłowska J., Ekonomia jako nauka pozytywna. Refleksje na marginesie "Ekonomii dobra i zła” Tomasa Sedlacka, “Annales, Etyka w Życiu Gospodarczym” 2013, No. 16, pp. 335-344.

Dzionek-Kozłowska J., R. Matera, Ethics in Economic Thought. Selected Issues and Various Perspectives, Lodz University Press \& Jagiellonian University Press, Lodz-Cracow 2015, pp. 81-89.

Horkheimer M., Krytyka instrumentalnego rozumu, Scholar, Warsaw 2007.

Horkheimer M., T. Adorno, Dialektyka Oświecenia. Fragmenty filozoficzne, Wydawnictwo IFiS PAN, Warsaw 1994.

Keynes J.M., Economic Possibilities for Our Grandchildren [in:] Essays in Persuasion, Macmillan, London 1931, pp. 358-374.

Korsgaard C., The Constitution of Agency: Essays on Practical Reason and Moral Psychology, Oxford Scholarship Online, Oxford 2009, pp. 25-99.

\footnotetext{
${ }^{19}$ Compare: M. Horkheimer, op. cit., pp. 64-65.
} 
Kuderowicz Z., Czy Kant wierzyt w postęp? [in:] Kant wobec problemów współczesnego świata, eds. J. Miklaszewska, P. Spryszak, Jagiellonian University Press, Cracow 2006, pp. 13-17.

McLuhan M., Zrozumieć media: przedtużenia czlowieka, Wydawnictwa Naukowo-Techniczne, Warsaw 2004.

Miklaszewska J., Kantowska utopia racjonalności [in:] Kant wobec problemów współczesnego świata, eds. J. Miklaszewska, P. Spryszak, Jagiellonian University Press, Cracow 2006, pp. 75-86.

Stewart H., A Critique of Instrumental Reason in Economics, "Economics and Philosophy" 1995, Vol. 11, pp. 57-83. 